\title{
Two new Tursiocola species (Bacillariophyta) epizoic on green turtles (Chelonia mydas) in French Guiana and Eastern Caribbean
}

\author{
Catherine Riaux-Gobin ${ }^{1,2^{*}}$, Andrzej Witkowski ${ }^{3}$, Damien Chevallier ${ }^{4} \&$ \\ Genowefa DANISZEWSKA-KowALCZYK ${ }^{3}$
}
${ }^{* 1}$ PSL Research University: CNRS-UPVD-EPHE, USR3278 CRIOBE, '2 Laboratoire d'Excellence 'CORAIL' University of Perpignan, F-66860 Perpignan, France; *Corresponding author e-mail: catherine.gobin@ univ-perp.fr
${ }^{3}$ University of Szczecin, The Faculty of Geosciences, Palaeoceanology Unit, PL-70-383 Szczecin, Poland, witkowsk@univ.szczecin.pl
${ }^{4}$ UMR 7178-CNRS-Unistra, Institut Pluridisciplinaire Hubert Curien, FR-67087 Strasbourg, France, da- mien.chevallier@iphc.cnrs.fr

\begin{abstract}
Scrapings from several juvenile Chelonia mydas LinNaEus (green turtle) from Eastern Caribbean and adults from French Guiana allowed for the description of two small and relatively rare epizoic Tursiocola species (Bacillariophyta). Differences with the other eight Tursiocola species previously described are discussed here. Particular attention is given to the cingulum of the two new species and a conceptual key is proposed for Tursiocola species, based on the cingulum structure.
\end{abstract}

Key words: Epizoic diatoms, sea turtles, Tursiocola, morphology, autecology

\section{INTRODUCTION}

Between 1920 and 1958 (Bennet 1920; Hart 1935; OMuRa 1950; Hustedt 1952; Окuno 1954 and Nемото $1956,1958)$ and more intensively during the last three decades, increasing interest was given to epizoic diatoms (see Holmes 1985; Van Bonn \& Denys 1997; Denys 1997; Frankovich et al. 2015a). This has led to the description of several genera exclusive to this type of habitat. The first detailed taxonomic investigations concerned diatoms known to colonize whales, with the creation of two new achnanthoid genera Bennettella R.W.Holmes and Epipellis R.W.Holmes (e.g., Holmes 1985; Holmes \& Nagasana 1995; Denys \& Van Bonn 2001; Denys \& De Smet 2010). Until now, both genera were only known in association with cetaceans. After 1985, several new diatom genera and species were discovered and shown to colonize metazoans (e.g., molluscs, holothurians; see Tотті et al. 2011; RIAUX-GobIN \& WitKowski 2012) and vertebrates (e.g., cetaceans, turtles and manatees) from contrasting environments (Holmes et al. 1993a,b; VAn Bonn \& Denys 1997; Denys 1997; Frankovich et al. 2015a,b; Pavlov et al. 2016; RiauX-Gobin et al. 2017), including the new genera Plumosigma T.Nemoto (Nемото 1956), Epiphalaina R.W.Holmes, Nagasawa \& TAKano (Hol- mes et al. 1993a), Tursiocola R.W.Holmes, NAgAsawa et Takano (Holmes et al. 1993a), Tripterion R.W.Holmes, Nagasawa et Takano (Holmes et al. 1993a), Chelonicola Majewska, De Stefano et Van de Vijver (MAJewska et al. 2015), Poulinea Majewska, De Stefano et VAn de ViJver (Majewska et al. 2015) and Medlinella Frankovich, Ashworth et M.J.Sullivan (Frankovich et al. 2016).

The species within the genera Epiphalaina and Tursiocola show very similar morphologies and are characterized by their small size, an acicular shape and the presence of pseudosepta. They mainly differ through an internal butterfly-shaped structure in Tursiocola (Holmes et al. 1993a: p. 7). Eight Tursiocola species are currently reported in the literature, with $T$. podocnemicola C.E.Wetzel, VAN DE VIJVER et ECTOR from a freshwater turtle Podocnemis erythrocephala SpIX (Wetzel et al. 2012), T. denysii Frankovich et M.J.SuLLIVAN from a Loggerhead sea turtle Caretta caretta (LinNeaus) (Frankovich et al. 2015b), three taxa from a manatee from Florida Bay (Frankovich et al. 2015a), and the other taxa from whales and Dall's porpoises (Nemoto 1956; Holmes et al. 1993a,b; Denys 1997). Only three Epiphalaina taxa have been described thus far, and all were from cetaceans (Nемото 1956; Holmes et al. 1993a,b; Denys 1997). As reported by 
WETzEL et al. (2012), Brady (2010) also found an unidentified Epiphalaina or Tursiocola species on several species of marine turtles from the Gulf of Mexico. Recently, RoBInson et al. (2016) illustrated a Tursiocola sp. (ref. cit. fig. 2,D).

Scrapings from several juvenile Chelonia mydas LinNAEus (green turtle) from the Lesser Antilles (Eastern Caribbean) and adults from French Guiana allowed for the description of two additional species that can be assigned to Tursiocola due to their characteristic internal structure. Differences with the eight previously described Tursiocola species are discussed here. Particular attention is given to the cingulum complex of both new species.

\section{Material And Methods}

Materials used in this study were derived from two sources: 1) scrapings from the carapace of several wild juvenile Chelonia mydas from Martinique Island (Grande Anse d'Arlet $14^{\circ} 30^{\prime} 10.95^{\prime \prime} \mathrm{N}, 61^{\circ} 05^{\prime} 13.00^{\prime \prime} \mathrm{E}$ and Anse du Bourg $14^{\circ} 29^{\prime} 13.43^{\prime \prime} \mathrm{N}, \quad 61^{\circ} 04^{\prime} 58.88^{\prime \prime} \mathrm{E}, \quad 12-13$ October 2015, CNRS-IPHC survey), 2) scrapings from the carapace of several nesting adult Chelonia mydas in Aztèque, French Guiana (48 51' 45.81"N, $2^{\circ} 17^{\prime} 15.331 " \mathrm{\prime}$, 07 April 2016). The latter samplings were carried out by D.C. during ANTIDOT surveys (CNRS-IPHC program) which investigated the migratory behavior of several species of marine turtles, using genomic, Capture-Mark-Recapture (CMR) and satellite tracking to understand the migration behavior of the different turtle species.

The samples were all very small and the described taxa are relatively scarce. For light microscope (LM) examination, the samples were washed with distilled water to remove salts, treated with $30 \% \mathrm{H}_{2} \mathrm{O}_{2}$ for $2 \mathrm{~h}$ at $70{ }^{\circ} \mathrm{C}$ to remove organic matter, rinsed several times in distilled water, alcohol-desiccated and mounted on glass slides using Naphrax $^{\circledR}$. Diatom slides were examined with a Zeiss Axiophot 200, with differential interference contrast (DIC) optics and photographed with a Canon PowerShot G6 digital camera (CRIOBE-USR 3278, Perpignan, France). For SEM examination, the samples were filtered through $1 \mu \mathrm{m}$ Nuclepore $^{\circledR}$ filters and rinsed twice with deionised (milliQ) water to remove salts. Filters were air-dried and mounted onto aluminum stubs before coating with gold-palladium alloy (EMSCOP SC 500 sputter coater) and examined with a Hitachi $\mathrm{S}-4500$ SEM operated at $5 \mathrm{kV}$, calibrated with a Silicon grating TGX01 (C2M, Perpignan, France).

'Foot pole' (F) and 'head pole' $(\mathrm{H})$ refer to 'the length between the apex of the valve (foot or head) and the middle of the central area of the valve'. The ratio $(\mathrm{F} / \mathrm{H} \pm \sigma)$ is an approximate measure of the degree of heteropolarity of the cell. Terminology and abbreviations. For the description of the frustule and its parts, terminology follows Anonymous (1975), Ross et al. (1979) and Round et al. (1990).

\section{RESUlts}

In addition to Chelonicola spp. and Tripterion spp., several of the turtle scrapings revealed two rare and acicular taxa from the genus Tursiocola. One very small sample ('31CM' from a nesting Chelonia mydas from Aztèque, see Mat. \& Meth.) was found to have both Tursicola species, one of which is very rare. In LM it is almost impossible to separate and correctly discriminate the two latter taxa.

Light microscopy (Figs 1-12): A total of 12 frustules or valves were photographed (Figs 1-12). Pseudosepta are visible on each image. The striation of the valves is barely visible and difficult to resolve. Figs 7-12 likely illustrate the dominant species (Tursiocola yin-yangii sp. nov., see below), which is slightly more acicular and smaller than the second taxon ( $T$. guyanensis $\mathrm{sp}$. nov.) possibly illustrated in Fig. 6 (see SEM description of each taxon). In cingular view (Figs 1-5) it is almost impossible to distinguish between the two taxa, as their stria densities are very similar (see below).

Taxonomic notes: In LM, Tursiocola yin-yangii sp. nov. and T. guyanensis sp. nov. are most similar to Tursiocola staurolineata Denys (Denys 1997, figs 42a52) and T. olympica (Hustedt) Holmes, Nagasawa et TaKano (DenYs 1997, figs 65-75; Frankovich 2015b, figs 31-33), except for their average smaller size. However, these two species are also similar to Epiphalaina aleutica var. aleutica (Holmes et al. 1993a, figs 1-2; Denys 1997, figs 1-10) and to E. aleutica var. lineata (DENYs 1997, figs 24-39, no SEM). SEM was therefore essential for a full description of the new taxa.

Tursiocola yin-yangii RIAUX-GobIN et WITOWSKI sp. nov. (Figs 7-12, 13-29)

Description: Valves small, acicular, with acute apices $[\mathrm{n}=66(\mathrm{SEM}) ; 8.7-14.5 \mu \mathrm{m}$ (mean $\pm \sigma \quad 11.7 \pm 1.4)$ long; $1.32-1.37 \mu \mathrm{m}$ wide; $36-42.8$ striae in $10 \mu \mathrm{m}$ (mean $\pm \sigma 39.7 \pm 1.6$ ); length/width 7.8 (Table 1)]. Frustule biraphid, isovalvar, rectangular in girdle view. Valve face not cuneate. Very slight difference between the length of the raphe branches (see SEM morphology). Pseudosepta present. Complex cingulum composed of numerous narrow copulae (see SEM). Never in chains. Found as epizoic on Chelonia mydas.

\section{SEM morphology}

Externally: Pole showing the valvocopula closed pole [with a second short row of puncta (see below)] is just slightly longer than the other pole $(n=27$, ratio $\mathrm{F} / \mathrm{H}$ $\pm \sigma 0.99 \pm 0.05$ ), e.g., the specimen illustrated in Fig. 16 has a head pole that is significantly longer than the foot pole and a slightly cuneate shape in girdle view (foot pole slightly narrower). Valve margins straight to slightly undulate. Striae uniseriate, parallel to slightly radiate, denser on both apices. Each stria is composed of four areolae externally ornamented by an 'S'-shaped opening resembling a yin-yang symbol (Figs 14-15, 17, 19-22). Each areola is internally closed by a round and domed hymenate pore occlusion (Fig. 28, position 
of slits or perforations is not apparent in SEM). Presence of a relatively wide and slightly bow-tied stauros (the striae delineating the central area are divergent, Figs 14-15), void of areolae up to the margins and externally thickened (Figs 14-15). Raphe filiform and straight. Proximal raphe endings well separate, spathulate and straight-coaxial (Fig. 14). Terminal raphe fissures hooked on the same side and terminating in a sort of contorted areola (Fig. 17). Small apical area void of areolae (Fig. 17 arrow). Cingulum composed of up to 5 copulae on each valve. The valvocopula appears to be open and narrow, with one advalvar row of round puncta which are slightly denser than the striae, and a supplementary short row of scarce and larger puncta on its closed pole. These supplementary puncta, symmetrically positioned on both valves (Fig. 21 arrowheads), give a polarity to the frustule. The pole with the supplementary puncta (on the closed pole of the valvocopulae) may correspond to the head pole of the frustule (Fig. 23 arrowhead). The other copulae (up to four) are open, narrow and show only one row of puncta (Figs 19-22).

Internally: A pseudoseptum extends from the apices as siliceous plates covering ca. one-fourth of the valve length on each apex (Figs 24-26). The pseudoseptum continues as very narrow strips along the valve margins (Fig. 28 arrows), and widens into two concave wings in the central area, creating a relatively narrow 'butterfly-like' structure (Figs 24, 28). The raphe lies, more or less symmetrically, on the top of a siliceous rib (Fig. 28). One unique pearl-like knob lies in between the proximal raphe endings (Fig. 28). On cleaned mate-
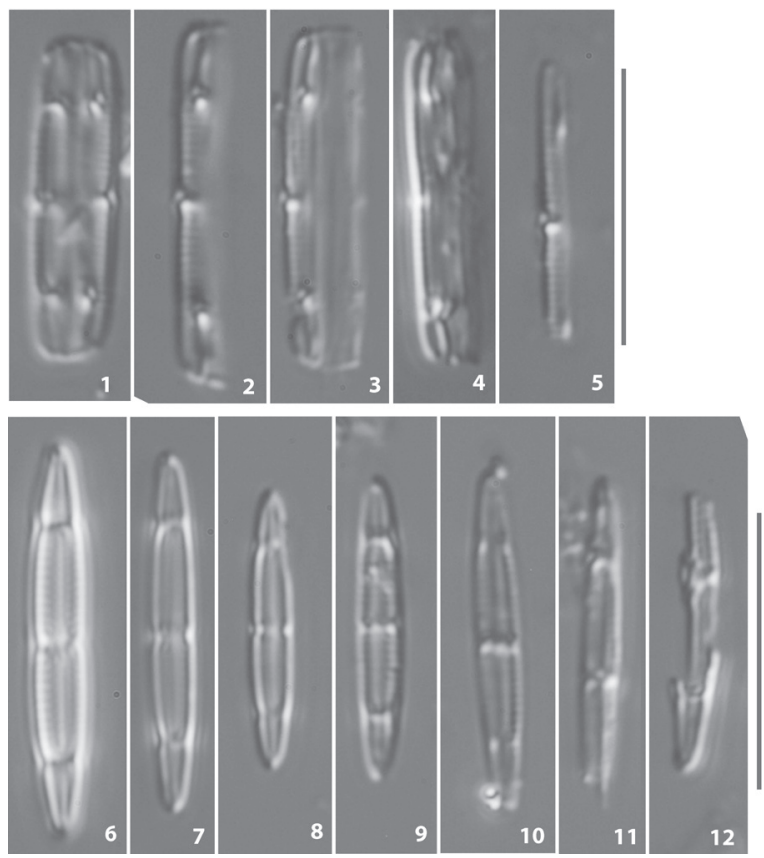

Figs 1-12 (LM): (7-12) Tursiocola yin-yangii sp. nov.; (6) Tursiocola guyanensis $\mathrm{sp}$. nov. Note the pseudoseptae and the barely visible valve striation. In girdle view (Figs 1-5) it is almost impossible to distinguish between the two taxa. Scale bars $10 \mu \mathrm{m}$. rial, it is possible to see the 'S-shaped' external opening of each areola (Fig. 27 arrow) through the internal corroded hymenes (Fig. 27 arrowhead shows the periphery of the corroded hymen).

Holotype: Specimen on the SEM stub BM001231764 (National History Museum, London, U.K.) illustrated in Fig. 13.

Isotypes (Here designated): Slide BM 101856 (Natural History Museum, London, UK), Slide SZCZ 24042 in collection A. WitKowsKi (The Faculty of Geosciences, Szczecin, Poland).

Type locality: Nesting Chelonia mydas from French Guiana (Site 'Aztèque') (48 51'45.81"N, 2 ${ }^{\circ} 17^{\prime}$ 15.331"E). Sample named '31CM'. Sampling date: 07 04 2016. Collector: Damien ChevalLier.

Etymology: The epithet was given in reference to the ' $\mathrm{S}$ '-shaped external opening of the areolae, resembling a yin-yang symbol.

Habitat: Wild nesting Chelonia mydas in French Guiana.

Taxonomic notes: Characterized by its small size, narrow and linear shape, complex cingulum and unique external areola opening, this taxon is relatively easy to distinguish from other Tursiocola species (Table 1).

\section{Tursiocola guyanensis RIAUX-GoBIN et WITOWSKI sp. nov., Figs 30-44.}

Description: Very rare, valves small, narrow-elliptical to acicular, with round apices $[\mathrm{n}=21$ (SEM); 12-13.9 $\mu \mathrm{m}$ (mean $\pm \sigma 12.9 \pm 0.7$ ) long; $1.70 \mu \mathrm{m}$ wide; $33-$ 40.6 striae in $10 \mu \mathrm{m}$ (mean $\pm \sigma 37.9 \pm 1.7$ ); length/ width ca. 7.8]. Frustule biraphid, isovalvar, rectangular in girdle view. Very slightly heteropolar, though the difference between the length of the raphe branches is difficult to discern (see SEM morphology). Speudosepta present. Complex and wide cingulum composed of numerous copulae (see SEM). Never found in chains in fresh material. Epizoic on Chelonia mydas.

\section{SEM morphology}

Externally: Valve margins with three undulations (Fig. 30). Pole of the frustule showing the closed pole of the copula $n^{\circ} 2$ (see below), very slightly longer than the other pole. Striae uniseriate, in higher densities on both apices, parallel to very slightly divergent on mid-valve, composed most often of four oblong transapically elongate areolae that are constricted two to three times along their length (Fig. 31 arrowhead). Areolae close to the raphe are diamond-like or quadrangular (Figs 33 arrowhead). Areolae of the apex, near the mantle, often vermiform or with three (or more) constrictions (Fig. 34 arrowhead). Areolae internally closed by domed hymenes (Fig. 44, arrowhead, slits or perforations not apparent in SEM). Relatively large stauros (slightly bow-tied, Fig. 32), void of areolae up to the margins, externally thickened. Raphe straight. 

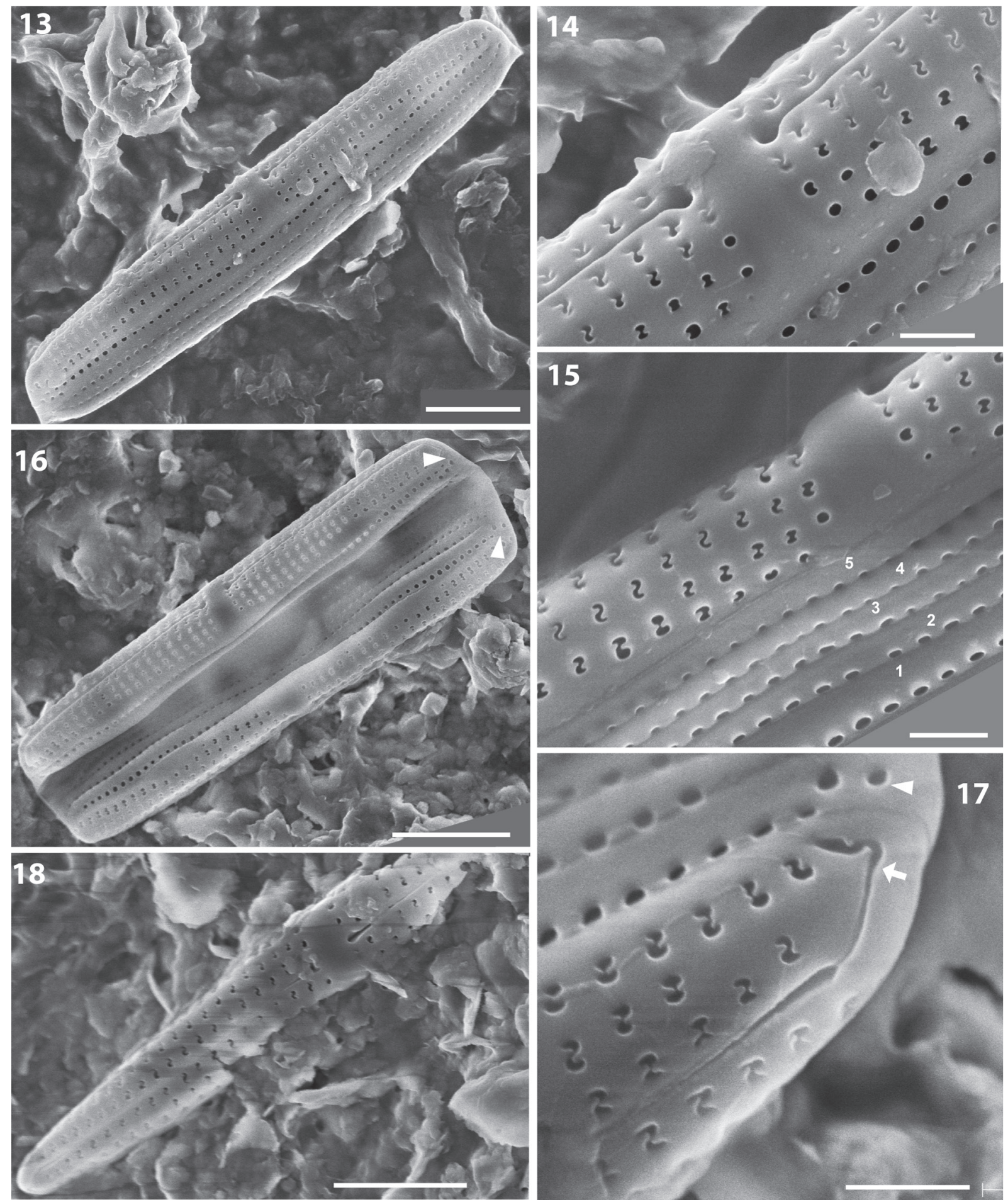

Figs 13-18 (SEM external views), Tursiocola yin-yangii sp. nov.: (13) holotype specimen; $(13,16)$ entire frustules, $(16)$ specimen slightly wedge-shaped in girdle view, foot pole slightly narrower, and head pole with the valvocopulae closed poles (arrowheads); (15) striae composed of two rows of sigmoid areolae; (14) central area with a domed fascia and spathulate proximal raphe endings; (15) striae composed of three to four areolae; (16) somewhat spaced slightly narrower near both poles; (18) frustule acicular in valve view; (17) detail of apex (head pole) with a terminal raphe ending terminating in a contorted areola (arrow) and the valvocopula showing one row of round puncta and a supplementary row of scattered larger puncta (arrowhead). Scale bars $3 \mu \mathrm{m}(16) ; 2 \mu \mathrm{m}(13,18) ; 500 \mathrm{~nm}(14,15,17)$. 

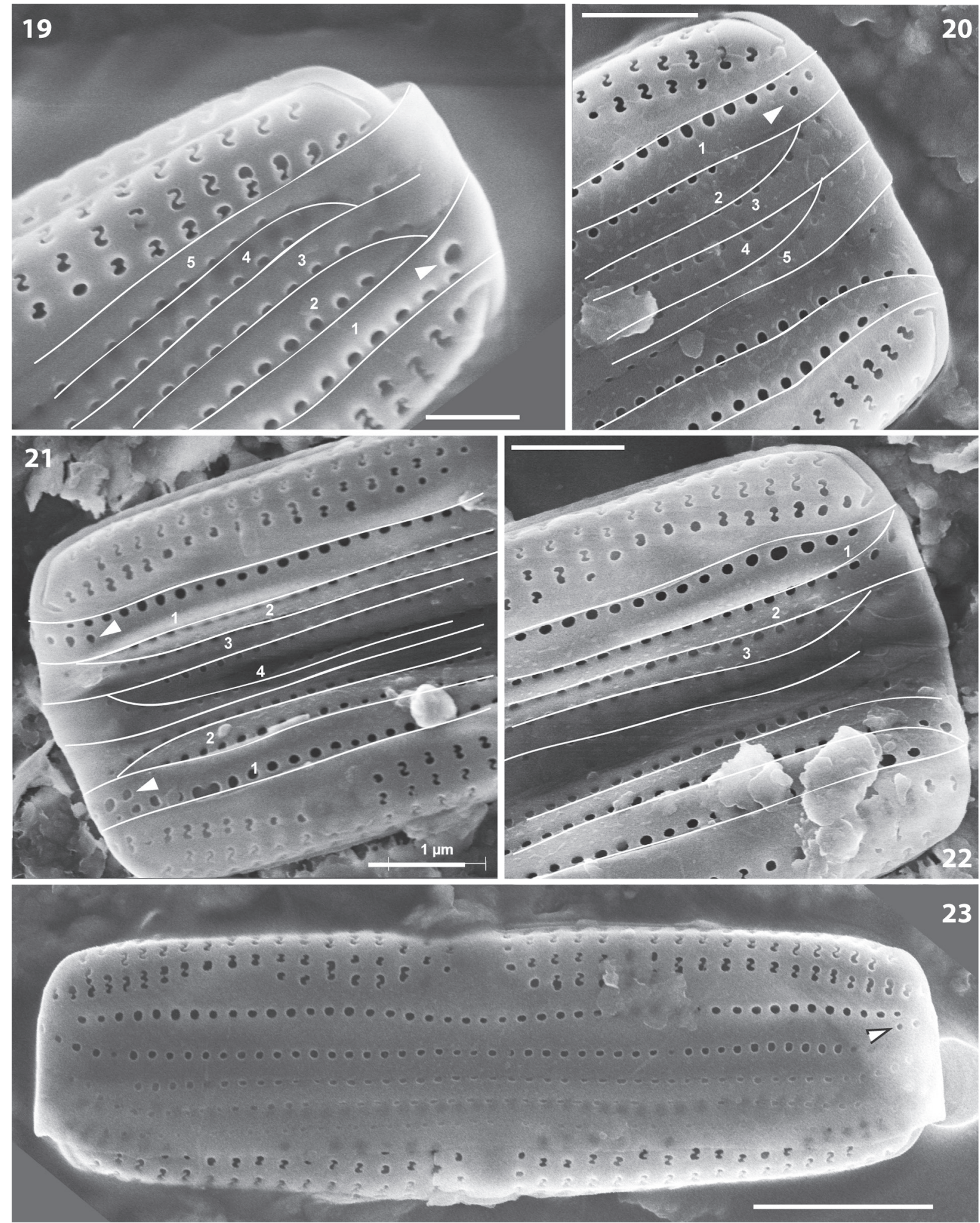

Figs 19-23 (SEM, external views). Tursiocola yin-yangii sp. nov.: (23) entire frustule in girdle view with the head pole showing the closed pole of the valvocopula (framed arrowhead); (19-22) the margins of the cingular bands are demarcated; (19-21) details of the frustule head pole with the closed apex of the valvocopula (arrowheads, copulae annotated ' 1 ') and open supplementary copulae (annotated ' 2 ' to ' 5 '); (22) detail of the frustule foot pole with the open apex of the valvocopula; $(21,22)$ the same frustule. Scale bars $2 \mu \mathrm{m}(23) ; 1 \mu \mathrm{m}(20-22) ; 500 \mathrm{~nm}(19)$. 

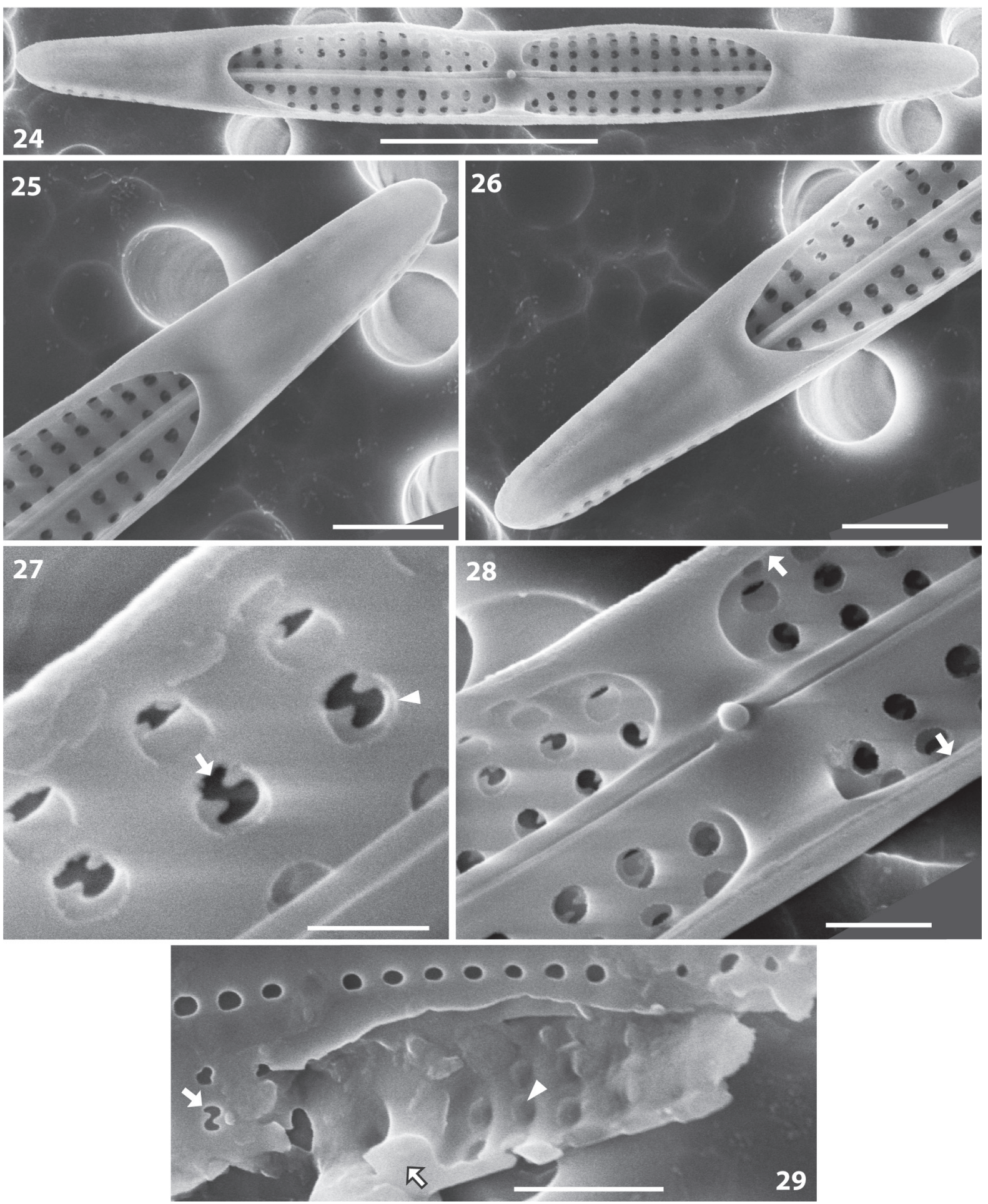

Figs 24-29 (SEM, internal views), Tursiocola yin-yangii sp. nov.: (24) entire valve; (25-26) details with the pseudoseptum extending on both apices and continuing as narrow strips along the margins; (27) striae are parallel. Detail of the areolae with corroded hymenes (arrowhead) and underlying sigmoid areola apertures (arrow). (28) detail of the central area with the butterfly structure, raphe slightly lateral and a single knob in between the proximal raphe endings, note the narrow strips along the valve margins; (29) broken frustule with the sigmoid external areola apertures (arrow), the section of the butterfly structure (framed arrowhead) and the internally domed areola hymenes (arrowhead). Scale bars $3 \mu \mathrm{m}$ (24), $1 \mu \mathrm{m}$ (25-26), $700 \mathrm{~nm}(29), 400 \mathrm{~nm}$ (28), $200 \mathrm{~nm}(27)$. 

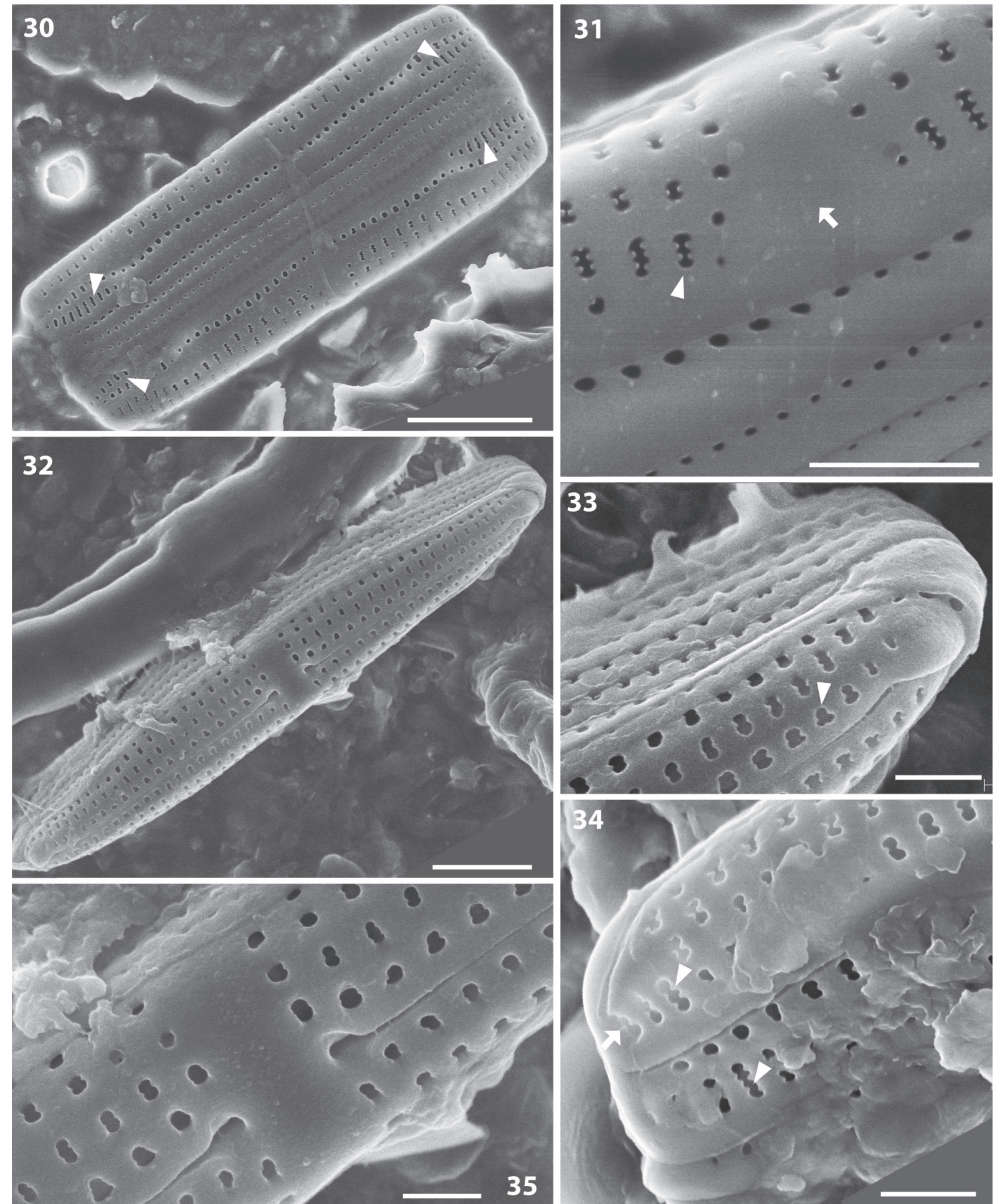

Figs 30-35 (SEM). Tursiocola guyanensis sp. nov.: (32) frustule in valve view; (30) frustule in girdle view, valvocopula apices with vermiform puncta (arrowheads); (35) central area with a fascia and spathulate proximal raphe endings; (31) fascia in girdle view (arrow), areolae vermiform with two to three constrictions (arrowhead); (33) detail of the valve apex with a reinforcement in one side of the terminal raphe ending, and diamond-like areolae near the raphe (arrowhead); (34) apex in girdle view with the raphe ending terminating in a contorted areola (arrow), areolae vermiform on the mantle and on the valvocopula apex (arrowheads). Scale bars $3 \mu \mathrm{m}(30), 2 \mu \mathrm{m}(32), 1 \mu \mathrm{m}(31), 500 \mathrm{~nm}(33-35)$. 

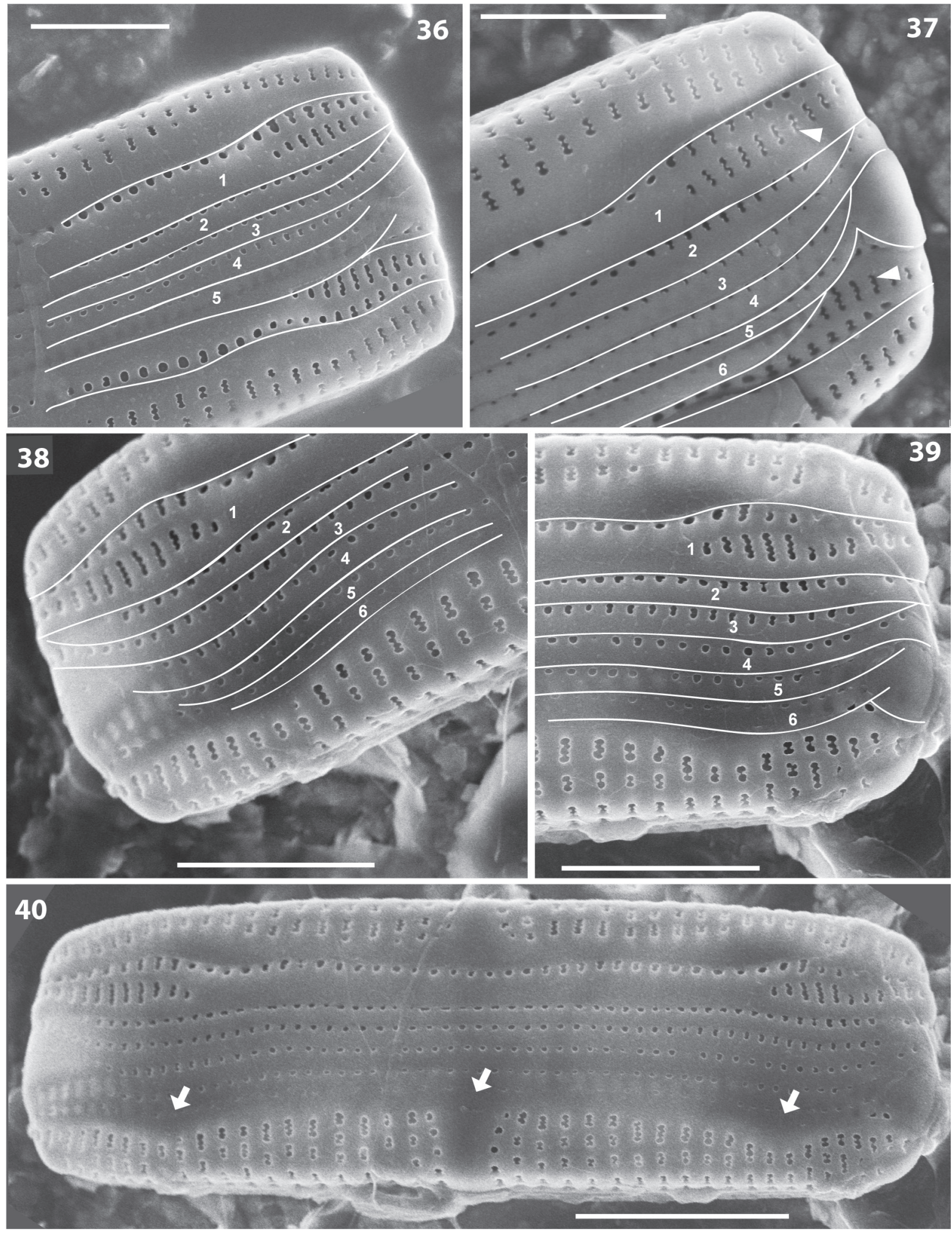

Figs 36-40 (SEM, external views), Tursiocola guyanensis sp. nov.: (40) entire frustule in girdle view with black shadows corresponding to the siliceous internal septa and central structures (arrows); (36-39) detail of the frustule apex (the margins of the cingular bands are demarcated) with vermiform puncta on the pole of the valvocopulae (annotated '1', Fig. 37 arrowheads), with the presence of 5 supplementary open copulae (annotated ' 5 ' to ' 6 '). Figs 39 (valve head pole, with the closed pole of the $2^{\text {nd }}$ copula) and Fig. 38 (valve foot pole) of the frustule illustrated in Fig. 40. Scale bars $3 \mu \mathrm{m}(40) ; 2 \mu \mathrm{m}(36-39)$. 
Proximal raphe endings coaxial, well separated and spathulate. Terminal raphe fissures strongly hooked on the same side, externally ending in a vermiform areola (Fig. 34 arrow). Small apical area void of areolae (Fig. 33). Wide cingulum, composed of numerous copulae (up to 6 per valve). The valvocopula is wide, with an advalvar row of round to oblong poroids and a second, abvalvar, apical row (1/4 of the valve length, on each apex) with transapically elongate and vermiform poroids (Fig. 37 arrowheads) with more or less the same density as the striae. The supplementary copulae have only one row of puncta that decrease in diameter from the $2^{\text {nd }}$ to the $6^{\text {th }}$ copula (e.g., in Figs 37,38 ). The $5^{\text {th }}$ and $6^{\text {th }}$ copulae are weakly silicified and narrow. Frustule head pole and foot pole are very similar and hard to distinguish. The closed pole of the $2^{\text {nd }}$ copula points out of the head pole of the cell.

The transapically elongate and vermiform puncta on both apices of the valvocopulae are very similar to the areolae on the valve apices (Figs 37-38 arrowheads). These vermiform puncta are present symmetrically on both apices of the valvocopula. The valvocopulae appear to be closed and present tabs standing on the wings of the central structure (Fig. 43). In cleaned material we found no free valvocopula, only narrow open cingular bands, impossible to be attributed to T. yin-yangii sp. nov. more than to T. guyanensis sp. nov. More observations are needed to clearly describe each cingular band.

Internally: Presence of a transverse, narrow and thickened structure (Figs 41-44), with lateral expansions reminiscent of a butterfly (Fig. 43 arrows). A picture of the entire pseudoseptum has not yet been obtained. In Fig. 40 (arrows) the black shadows at each pole of the frustule and on the central part, mark the presence of siliceous internal thickenings corresponding to the septa and central structures.

Holotype: Specimen on the SEM stub BM001231764 (National History Museum, London, U.K.) illustrated in Fig. 32.

Isotypes (Here designated): Slide BM 101856 (Natural History Museum, London, UK), Slide SZCZ 24042 in collection A. WitKowsKi (The Faculty of Geosciences, Szczecin, Poland).

Type locality: Nesting Chelonia mydas in French Guiana from 'Aztèque' (48 $51^{\circ} 45.81^{\prime \prime N}, 2^{\circ} 17^{\prime} 15.331$ "E). Sampling date: 0704 2016. Collector: Damien CHEVALLIER. Also present, as rare, on juvenile Chelonia mydas at 'Anse du Bourg', Lesser Antilles (14 29' 13.43"N, 6144 58.886”'W).

Etymology: The epithet guyanensis was given in reference to French Guiana (Guyane), the location where the species was first found.

Habitat: Nesting wild adult Chelonia mydas from French Guiana, host Tursiocola guyanensis sp. nov. In sample ' $31 \mathrm{CM}$ ', this latter taxon is rare, while $T$. yin-yangii sp. nov. is more abundant. T. guyanensis was also observed as very rare on 3 juvenile specimens of Chelonia mydas from Martinique Islands (Lesser Antilles). Until now, this species was not observed in samples taken from Chelonia mydas from the South Pacific, nor were they found on Dermochelys coriacea (leatherback turtle), or Lepidochelys olivacea (olive Ridley turtle) from Guiana.

Taxonomic notes: The internal central area of Tursiocola guyanensis (Figs 40-43), with a narrow silicified transverse structure and semblance of wings (Fig. 42 arrows), are characteristic of the genus Tursiocola. There are similarities between our taxon and T. denysii Frankovich et M.J.Sullivan in Frankovich et al. (2015b). T. denysii, like our taxon, has closed valvocopulae ornamented on their apices by a second row of puncta simply referred to as 'abvalvar pores' (ref. cit., fig. 28 arrow). In T. guyanensis sp. nov, the poroids are long and vermiform. Furthermore the valvocopulae in T. guyanensis sp. nov. are wide whereas those in $T$. denysii seem more narrow. Additional features that differentiate the two taxa include the following: T. guyanensis sp. nov. is more acicular than T. denysii (length/width = ca. 7 in T. guyanensis versus ca. 4.8 in T. denysii), with striae less strongly radiate, less areolae per stria and most likely a more complex cingulum. Furthermore, the areolae in T. denysii are described as 'transapically elongated' but not constricted in their middle.

A taxon presented as Tursiocola sp. from a leatherback turtle in RoBInSON et al. (2016, fig. 2-D), with an internal narrow transapical structure with lateral triangular wing-shaped expansions, and valvocopulae showing apices with a double row of puncta, may be similar to our new taxon.

\section{Discussion}

Several studies have attempted to find reliable characters to distinguish Tursiocola from Epiphalaina. Holmes et al. (1993a) suggested that the butterfly-like internal structure could serve to discriminate between the two latter genera (Table 1). Thereafter, Wetzel et al. (2012) pointed that the copulae in Tursiocola systematically have two rows of puncta versus only one in Epiphalaina. It is now clear that the latter does not hold and that the ornamentation of the copulae varies among Tursiocola species (FrANKOVICH et al. 2015a,b and present study, Table 1): For example, Tursiocola costata Frankovich et M.J.Sullivan has copulae with only one row of punctae (Table 1).

The two taxa reported here belong to Tursioco$l a$, and species from this genus may be differentiated ultrastructurally, particularly by the: 1) shape of the external areola opening, 2) external shape and width of the stauros, 3) proximal raphe endings shape, 4) complexity of the cingulum (simple or composed of 


\begin{tabular}{|c|c|c|c|c|c|}
\hline 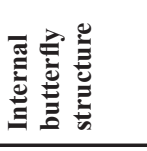 & + & 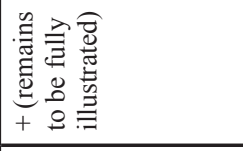 & + & + & + \\
\hline 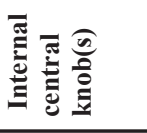 & $\begin{array}{l}0 \\
\stackrel{0}{\underline{g}} \\
=\end{array}$ & $\vec{J}$ & $\begin{array}{l}\text { 童 } \\
\text { D } \\
\text { है }\end{array}$ & 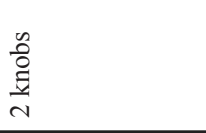 & $\begin{array}{l}\stackrel{0}{\circ} \\
\stackrel{\Xi}{=}\end{array}$ \\
\hline 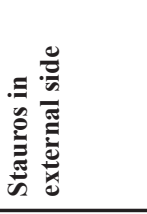 & 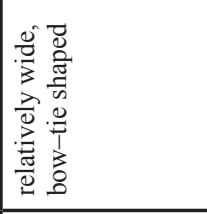 & 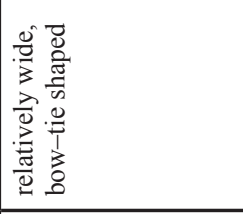 & 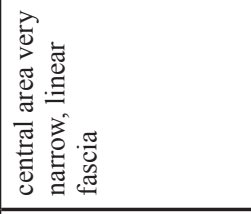 & 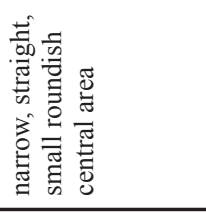 & 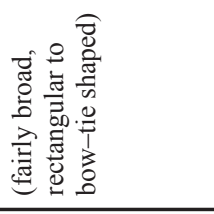 \\
\hline ن & 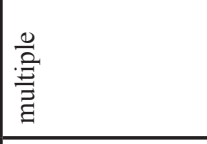 & 蒙 & $\bar{Z}$ & \multirow{2}{*}{ 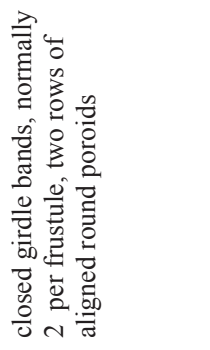 } & \multirow{2}{*}{ 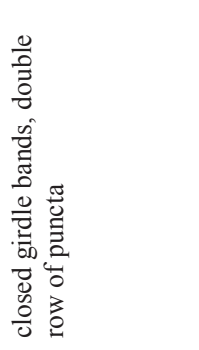 } \\
\hline 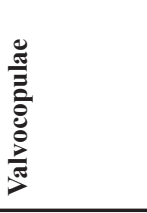 & 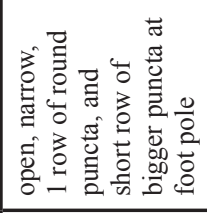 & 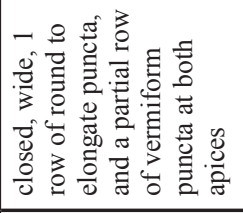 & 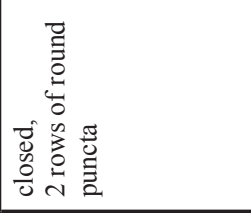 & & \\
\hline 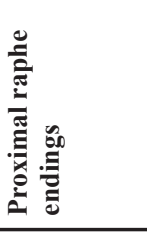 & 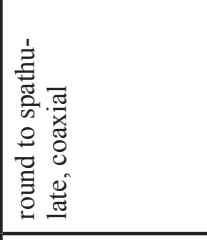 & 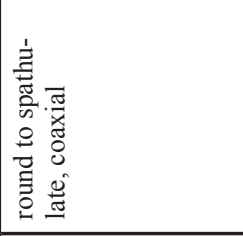 & $\Xi$ & 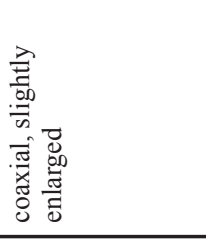 & 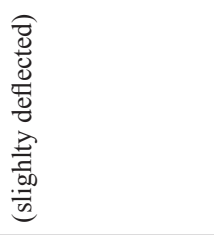 \\
\hline 竞 & 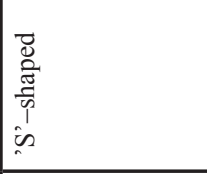 & 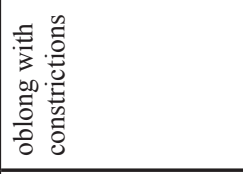 & 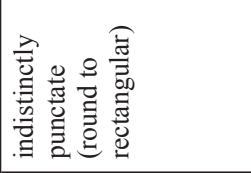 & 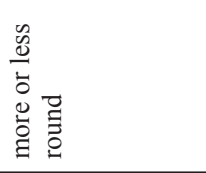 & 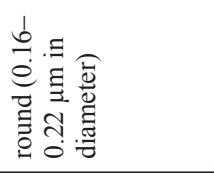 \\
\hline 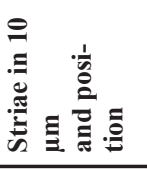 & 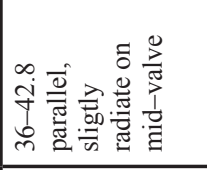 & 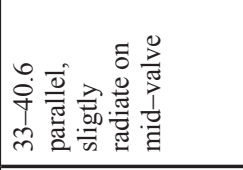 & 总 & 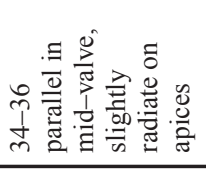 & 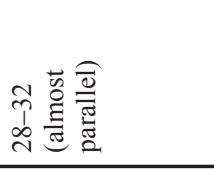 \\
\hline 言 & 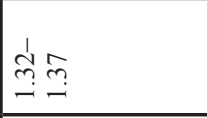 & 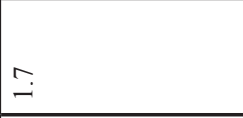 & f & $\begin{array}{l}\text { in } \\
\text { in } \\
\text { in } \\
\end{array}$ & $\begin{array}{l} \pm \\
\vdots \\
- \\
-\end{array}$ \\
\hline 喆 & 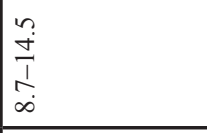 & 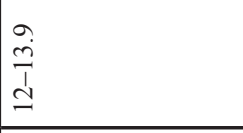 & 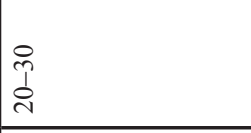 & $\begin{array}{l}\hat{\text { iे }} \\
\hat{i} \\
\text { a }\end{array}$ & $\begin{array}{l}n \\
\tilde{n} \\
n \\
\end{array}$ \\
\hline 总总 & 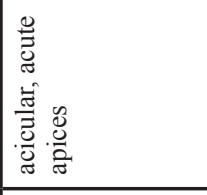 & 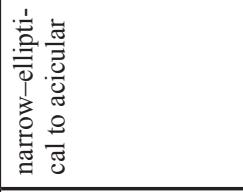 & 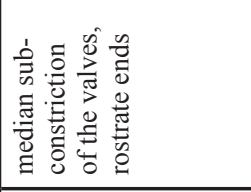 & 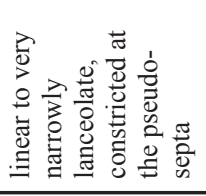 & 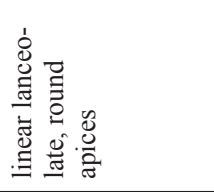 \\
\hline 竞 & 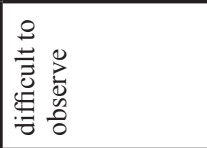 & 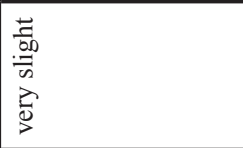 & $\Xi$ & $\begin{array}{l}\frac{\mathrm{t}}{\mathrm{og}} \\
\frac{\mathrm{op}}{\mathrm{s}}\end{array}$ & $\vec{g}$ \\
\hline & 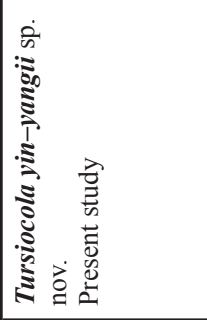 & 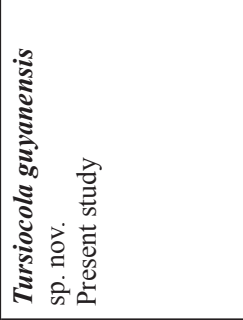 & 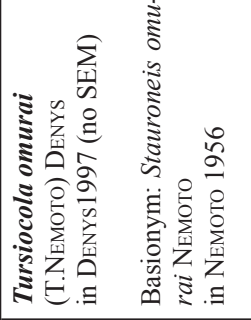 & 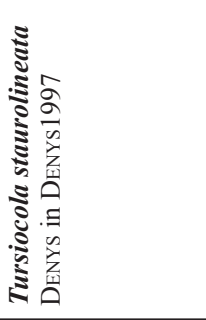 & 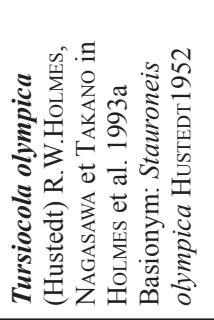 \\
\hline
\end{tabular}




\begin{tabular}{|c|c|c|c|c|c|c|c|}
\hline+ & + & + & + & + & 1 & \multirow{8}{*}{ 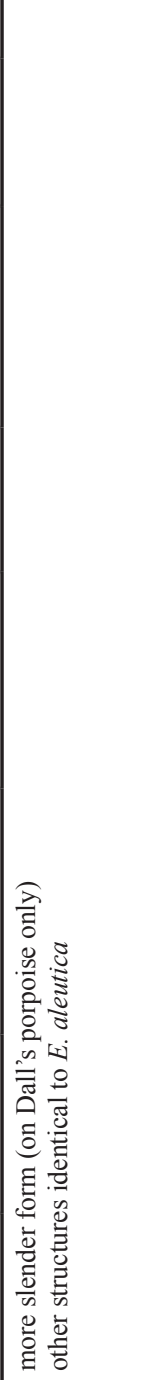 } & 1 \\
\hline 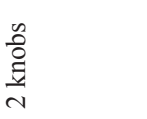 & $\begin{array}{l}\frac{n}{2} \\
\frac{g}{2} \\
\frac{0}{2}\end{array}$ & $\begin{array}{l}\frac{1}{2} \\
\frac{9}{0} \\
\frac{g}{2}\end{array}$ & $\begin{array}{l}\text { n } \\
0 \\
0 \\
\text { n }\end{array}$ & $\begin{array}{l}\stackrel{0}{\circ} \\
\stackrel{\Xi}{=}\end{array}$ & 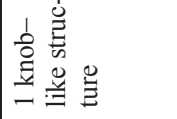 & & 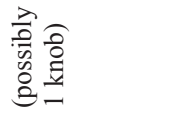 \\
\hline 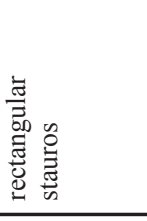 & 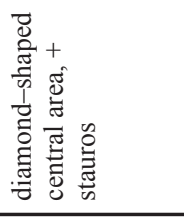 & 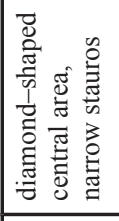 & 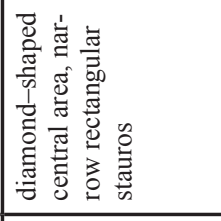 & 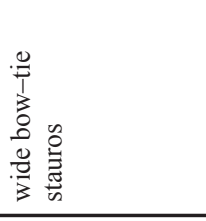 & 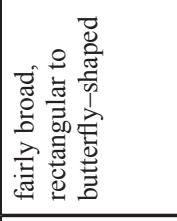 & & 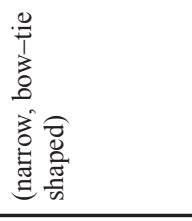 \\
\hline \multirow{2}{*}{ 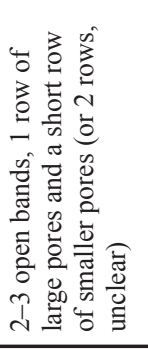 } & \multirow{2}{*}{ 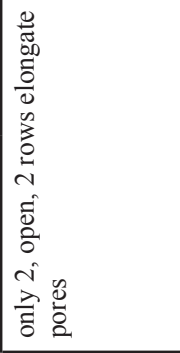 } & \multirow{2}{*}{ 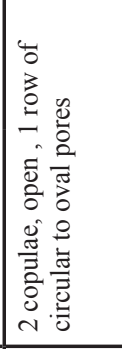 } & 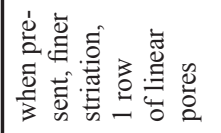 & $\begin{array}{l}\stackrel{+}{+} \\
\stackrel{0}{0} \\
\stackrel{0}{\Rightarrow}\end{array}$ & 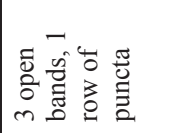 & & 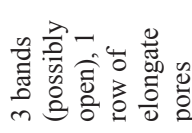 \\
\hline & & & 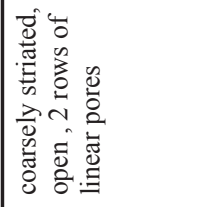 & 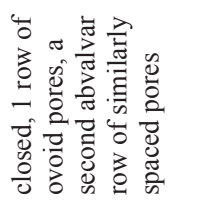 & 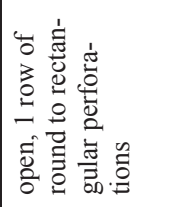 & & 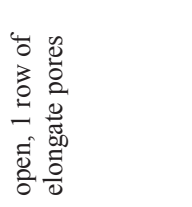 \\
\hline 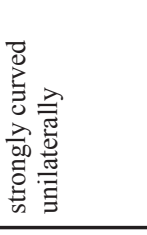 & 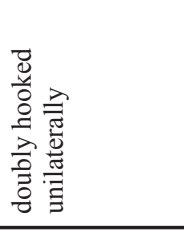 & 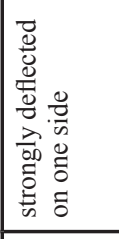 & 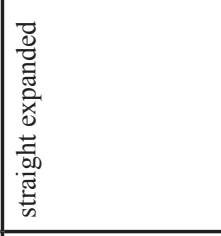 & 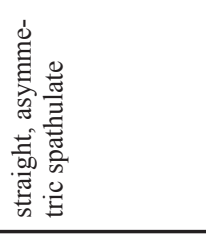 & 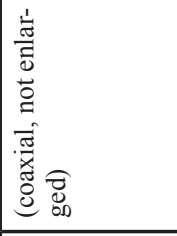 & & 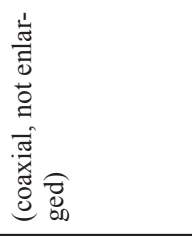 \\
\hline 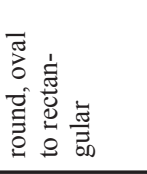 & $\overline{\frac{\pi}{5}}$ & 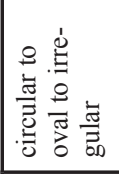 & 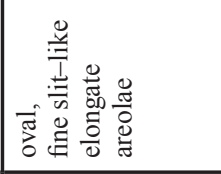 & 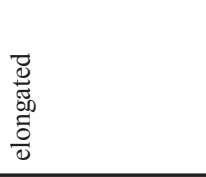 & 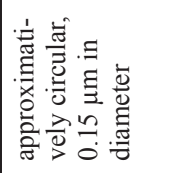 & & 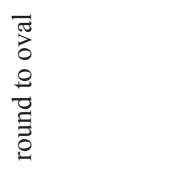 \\
\hline 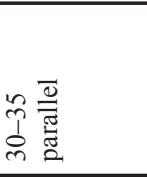 & 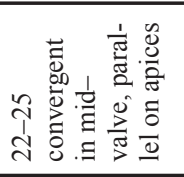 & 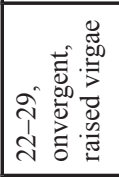 & 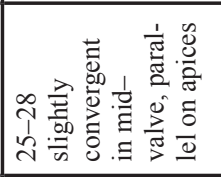 & 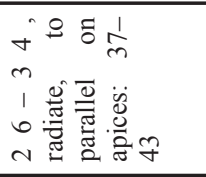 & 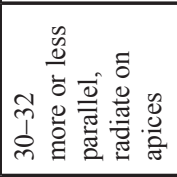 & & 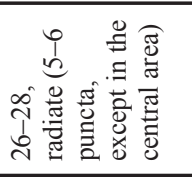 \\
\hline 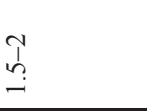 & $\begin{array}{l}n \\
i \\
b \\
i \\
i\end{array}$ & $\begin{array}{l}a \\
\dot{1} \\
n \\
i \\
i\end{array}$ & $\begin{array}{l}\hat{\dot{J}} \\
\text { aे } \\
\dot{i}\end{array}$ & $\begin{array}{l}\hat{i} \\
\text { d } \\
\end{array}$ & 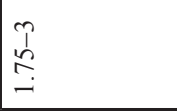 & $\stackrel{n}{i}$ & $\underset{i}{J}$ \\
\hline 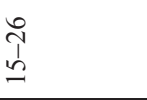 & $\begin{array}{l}\overrightarrow{0} \\
\stackrel{1}{1}\end{array}$ & $\begin{array}{l}\text { İ } \\
\text { I }\end{array}$ & $\frac{i}{m}$ & 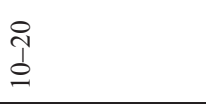 & 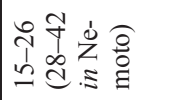 & & $\vec{p}$ \\
\hline 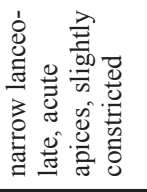 & 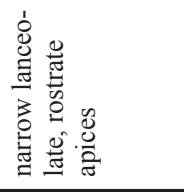 & 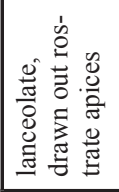 & 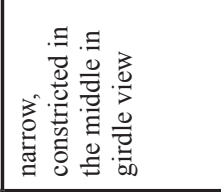 & 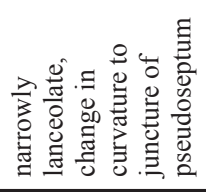 & 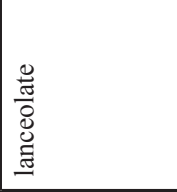 & 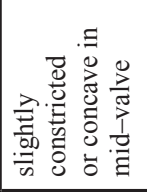 & 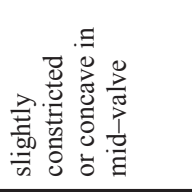 \\
\hline 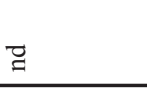 & 1 & + & 1 & $\begin{array}{l}\frac{\overrightarrow{5}}{.00} \\
\frac{.00}{\bar{m}}\end{array}$ & + & $\Xi$ & + \\
\hline 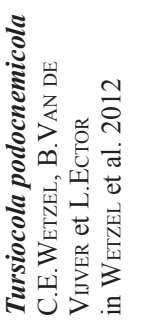 & 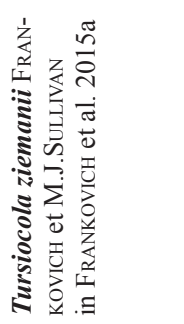 & 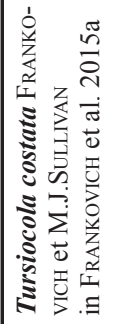 & 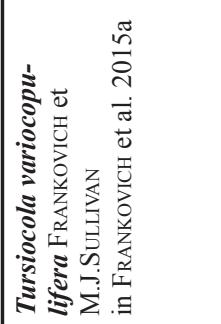 & 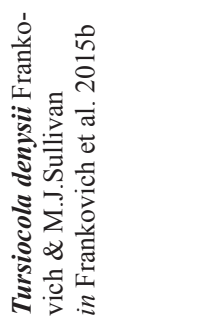 & 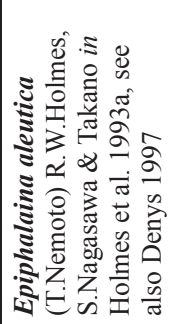 & 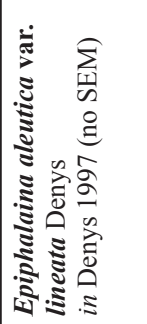 & 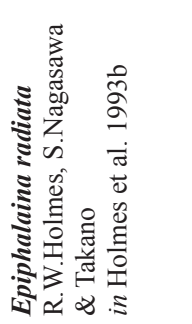 \\
\hline
\end{tabular}


multiple bands), 5) valvocopula and supplementary copula ornamentation (the puncta, sometimes identical in form and dimensions to the valve areolae, are not perforations and are closed by domed internal hymenes), 6) closed or open valvocopulae and copulae.

The valvocopula structure, and the presence of a short supplementary row of puncta at both poles (or at a single pole) of the valvocopulae and copulae, may be particularly good criteria to differentiate species. Unfortunately, all published taxa have not been examined with the same degree of EM accuracy, so some details concerning the number of copulae or their ornamentation, is not yet known.
Following Frankovich et al. (2015a,b) and their 'artificial' key based on diverse morphological features, Tursiocola denysii Frankovich et M.J.Sullivan and T. variocopulifera FrANKOVICH et M.J.SulLivan have valvocopulae that are different from their abvalvar copulae. T. guyanensis sp. nov. and T. yin-yangii sp. nov. also belong to this category. Nevertheless, some Tursiocola species are described as having only 2 cingular bands (valvocopulae with no supplementary bands), that are difficult to be qualified as 'undifferentiated'.

The following key primerily uses the structure of the cingulum and its diverse degree of complexity, to separate all currently known Tursiocola taxa.

Provisional key to Tursiocola species, mainly based on the cingulum:

1 more than 4 copulae per valve and valvocopulae different from abvalvar copulae.........................................2

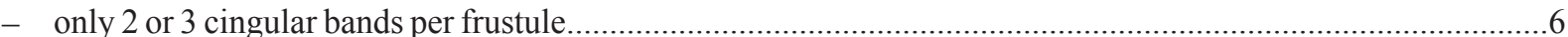

2 valvocopulae closed, with 1 row + short segment of ovoid puncta......................................................T. denysii

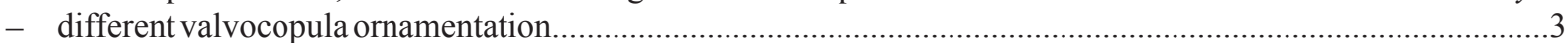

3 valvocopulae broad, with 1 row of round puncta + large segment of vermiform puncta .............T. guyanensis

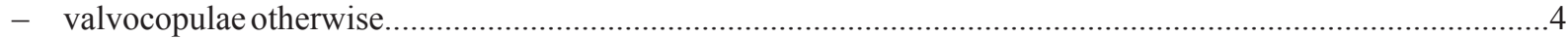

4 valvocopulae open, 2 complete rows of linear puncta...................................................... variocopulifera

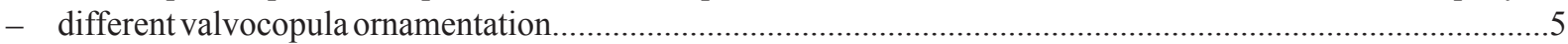

51 row of round puncta + short segment of scarce round puncta...................................................... T. yin-yangii

62 to 3 bands, open, 1 row + segment of smaller puncta........................................................ podocnemicola

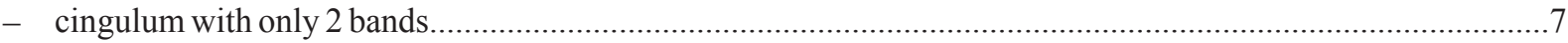

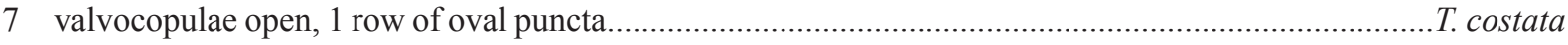

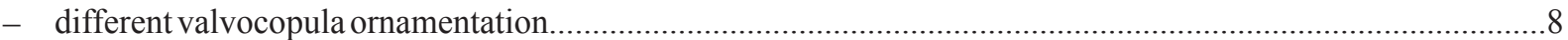

82 rows of elongate puncta......................................................................................................... ziemanii

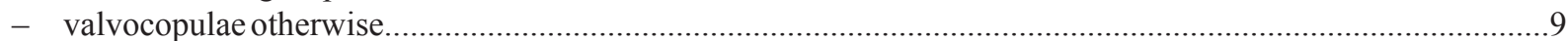

9 valvocopulae closed, 2 rows of round puncta................................................................................ staurolineata

- Idem, with broader and more rhombic stauros............................................................................. olympica

- Idem, with distinct median constriction and somewhat rostrated ends..........................................T. omurai

\section{ACKNOWLedgments}

Many thanks are due to Yonko Gorand (C2M, University of Perpignan, France) for assistance with the SEM and to Jeanine AlmanY (USR 3278 CRIOBE, EPHE-CNRS-UPVD) for improvements on the manuscript. An anonymous reviewer is acknowledged for his helpful comments and Aloisie PoulíčKovÁ and Petr HAŠLER (Editor in Chief and Technical editor) for their editorial help. Participation of AW and GD-K was financed from Topical subsidy of the Polish Ministry of Science and Education and DC appreciated the financial support of the ANTIDOT project (Pépinière Interdisciplinaire Guyane, Mission pour l'Interdisciplinarité, CNRS), the French Guiana Regional Council, the EDF Foundation and Fondation de France. We also acknowledge the Institut Pluridisciplinaire Hubert CURIEN UMR 7178-CNRS / Unistra and the CNRS-USR 3278-Labex CORAIL for supporting this research.

\section{REFERENCES}

AnONymous (1975): Proposals for a standardization of diatom terminology and diagnoses. - Nova Hedwigia Beihefte 53: 323-354.

Bennett, A.G. (1920): On the occurrence of diatoms on the Skin of Whales. - Proceedings of the Royal Society of London 91: 352-357.
Brady M. (2010): Turtletoms: what diatoms make sea turtles their homes? - In: Julius, M. \& EdLund, M.(eds): 21st International Diatom Symposium, abstracts. - p. 84. St. Cloud State University, St. Cloud, MN.

Denys, L. (1997): Morphology and taxonomy of epizoic diatoms (Epiphalaina and Tursiocola) on a sperm whale (Physeter macrocephalus) stranded on the coast of Belgium. - Diatom Research 12: 1-18.

Denys, L. \& De Smet, W.H. (2010): Epipellis oiketis (Bacillariophyta) on Harbour Porpoises from the north sea channel (Belgium). - Polish Botanical Journal 55: $175-182$.

Denys, L. \& Van Bonn, W. (2001): A second species in the epizoic diatom genus Epipellis: E. heptunei sp. nov.In: Jahn, R. et al. (eds): Lange-Bertalot-Festschrift: Studies on Diatoms. Dedicated to Prof. Dr. Dr. h. c. Horst Lange-Bertalot on the Occasion of his 65th Birthday. - pp. 167-176, Gantner Verlag: Ruggell ISBN 3-904144-26-X.

Frankovich, T.A.; Sullivan, M.J. \& Stacy, M.I. (2015a): Three new species of Tursiocola (Bacillariophyta) from the skin of the West Indian manatee (Trichechus manatus). - Phytotaxa 204: 33-48. doi: 10.11646/ 

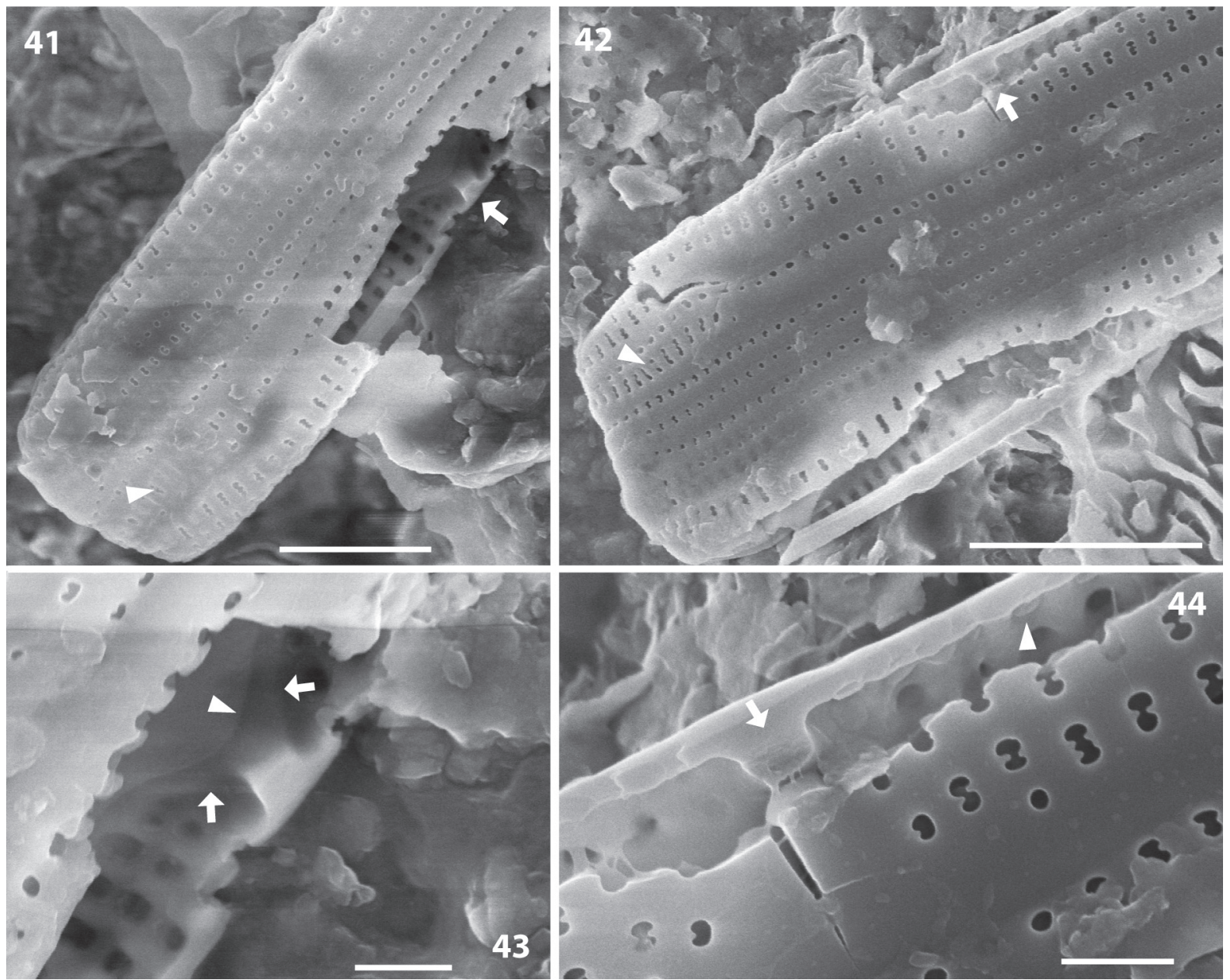

Figs 41-44 (SEM, internal views), Tursiocola guyanensis sp. nov.: (41) broken frustule showing the internal central structure (arrow) and the vermiform puncta on the pole of the valvocopula (arrowhead); (43) detail of Fig. 41 with the valvocopula median tab (arrowhead) standing on the lateral expansions of the butterfly structure (arrows); (42) broken frustule showing the internal central structure (arrow) and the vermiform puncta on the pole of the valvocopula (arrowhead); (44) detail of Fig. 42 with the broken and narrow butterfly structure (arrow) and the internally domed areola hymenes (arrowhead). Scale bars $3 \mu \mathrm{m}$ (42); $2 \mu \mathrm{m}$ (41); $500 \mathrm{~nm}(43-44)$.

phytotaxa.204.1.3

Frankovich, T.A.; Sullivan, M.J. \& Stacy, M.I. (2015b): Tursiocola denysii sp. nov. (Bacillariophyta) from the neck skin of loggerhead sea turtles (Caretta caretta). - Phytotaxa 234: 227-236. doi: 10.11646/phytotaxa.234.3.3

Frankovich, T.A.; Ashworth, M.P.; Sullivan, M.J.; Veselá, J. \& STACY, N.I. (2016): Medlinella amphoroidea gen. et sp. nov. (Bacillariophyta) from the neck skin of Loggerhead sea turtles (Caretta caretta). - Phytotaxa 272: 101-114.

HART, T.J. (1935): On the diatoms of the skin film of whales, and their possible bearing on problems of whale movements. - Discovery Reports Y: 247-282.

Holmes, R.W. (1985): The morphology of diatoms epizoic on cetaceans and their transfer from Cocconeis to two new genera, Bennettella and Epipellis. - British Phycological Journal 20: 43-57.

Holmes, R.W. \& NagasaWA, S. (1995): Bennettella constricta (Nemoto) Holmes and Bennettella berardii sp. nov. (Bacillariophyceae: Chrysophyta) as observed on the skin of several cetacean species. - Bulletin of the National Science Museum Tokyo, Series B (Botany),
Tokyo 21: 29-43, 4 pl.

Holmes, R.W.; Nagasawa, S. \& Takano, H. (1993a): The morphology and geographic distribution of epidermal diatoms of the Dall's porpoise (Phocoenoides dalli True) in the Northern Pacific Ocean. - Bulletin of the National Science Museum Tokyo, Series B (Botany), Tokyo 19: 1-18.

Holmes, R.W.; Nagasawa, S. \& Takano, H. (1993b): A reexamination of diatom samples obtained from cetaceans collected off South Africa. - Bulletin of the National Science Museum, Tokyo, Ser. B 19:127-135.

Hustedt, F. (1952): Diatomeen aus der Lebensgemeinshaft des Buckelwals (Megaptera nodosa Bonn.). - Archiv für Hydrobiologie 46: 286-298.

Majewska, R.; Kociolek, J.P.; Thomas, E.W.; De Stefano, M.; Santoro, M.; Bolaños, F. \& Van De Vijver, B. (2015): Chelonicola and Poulinea, two new gomphonemoid diatom genera (Bacillariophyta) living on marine turtles from Costa Rica. - Phytotaxa 233: 236-250. doi: 10.11646/phytotaxa.233.3.2

Nemoto, T. (1956): On the diatoms of the skin film of whales in the Northern Pacific. - Scientific Report of the Whales Research institute 11: 97-132. 
Nemoto, T. (1958): Cocconeis diatoms infected on whales in the Antarctic. - Scientific Report of the Whales Research institute 13: 185-191.

OKuno, H. (1954): Electron microscopical study on Antarctic diatoms (6) Observation on C. ceticola forming "Diatom film" on whales skin. - Journal of Japanese Botany 29: 271-277.

Omura, H. (1950): Diatom infection on Blue and Fin whales in the Antarctic whaling area V (the Ross sea area). - Scientific Report of the Whales Research institute 4: 14-26.

Pavlov, A.; Jovanovska, E.; Wetzel, C.E.; Ector, L. \& LevKov, Z. (2016). Freshwater Mastogloia (Bacillariohyceaea) taxa from Macedonia, with a description of the epizoic M. sterijovskii sp. nov. - Diatom Research 31: 85-112.

Riaux-Gobin, C. \& Witkowski, A. (2012): Small-sized and discoid species of the genus Cocconeisopsis (Bacillariophyta) on Holothuria atra (Juan de Nova, Mozambique Channel). - Phytotaxa 54: 43-58.

Riaux-Gobin, C.; Witkowski, A.; Kociolek, P.; Ector, L.; Chevallier, D. \& Compère, P. (2017): New epizoic diatom (Bacillariophyceae) species from sea turtles in the Eastern Caribbean and South Pacific. - Diatom Research 32: 109-125 DOI: 10.1080/0269249X.2017.1299042.

Robinson, N.J.; MaJewsKa, R.; LAZO-WASEM, E.A.; Nel, R.;
Paladino, F.V.; Rojas, L.; Zardus, J.D. \& Pinou, T. (2016): Epibiotic diatoms are universally present on all sea turtle species. - PLoS ONE 11: e0157011. doi:10.1371/journal.pone.0157011

Ross, R.; Cox, E.J.; Karayeva, N.I.; Mann, D.G.; Paddock, T.B.B.; Simonsen, R. \& Sims, P.A. (1979): An amended terminology for the siliceous components of the diatom cell. - Nova Hedwigia Beihefte 64: 513-533.

Round, F.E.; Crawford, R.M. \& Mann, D.G. (1990): The diatoms: Biology and Morphology of the Genera. 747 pp., Cambridge University Press, Cambridge.

Totti, C.; Romagnoli, T.; De Stefano, M.; Di Camillo, C.G. \& Bavestrello, G. (2011): The diversity of epizoic diatoms. - In: Dubinsky, Z. \& SeckBach, J. (eds): All flesh is grass. Cellular origin, life in extreme habitats and astrobiology 16. - pp. 323-343, Springer Book.

Van Bonn, W. \& Denys, L. (1997): Diatoms of the genus Epipellis in skin films of bottlenose dolphins (Tursiops truncatus) in San Diego Bay. - In: IAAAM 1997 (eds): IAAAM proceedings, 1997. - pp. 20-22.

Wetzel, C.E.; Van De Vijver, B.; Cox, E.J.; Bicudo, D. DE C. \& ECTOR, L. (2012): Tursiocola podocnemicola sp. nov., a new epizoic freshwater diatom species from the Rio Negro in the Brazilian Amazon Basin. - Diatom Research 27: 1-8. doi: 10.1080/0269249X.2011.642498
C) Czech Phycological Society (2017)

Received December 8, 2016

Accepted February 20, 2017 